\title{
Tryptic phosphopeptides from whole casein. II. Physicochemical properties related to the solubilization of calcium
}

\author{
BY RAFAEL BERROCAL, SERGE CHANTON, MARCEL A. JUILLERAT, \\ BLAISE PAVILLARD, JEAN-CLAUDE SCHERZ AND ROLF JOST \\ Nestlé Research Centre, Nestec Ltd, Vers-chez-les-Blanc, CH-1000 Lausanne 26, \\ Switzerland
}

\begin{abstract}
Summary. Casein phosphopeptides (CPP) were produced by tryptic hydrolysis of sodium caseinate and further purified by precipitation and chromatography on QAE-Sephadex A-25. Their physico-chemical properties were compared with the properties of an enzymically dephosphorylated equivalent preparation (DPP). Binding of $\mathrm{Ca}^{2+}$ to the peptides was measured using a Ca selective electrode and was found to increase with $\mathrm{pH}$ and to show $1 / 1$ stoicheiometry $\mathrm{Ca} / \mathrm{P}_{\text {org }}$ in $\mathrm{CPP}$ at $\mathrm{pH} 6.5$ and 7.6. Klotz plots indicated equivalent binding sites at these two $\mathrm{pH}$ values, but some heterogeneity was seen at $\mathrm{pH} 3.5$. In contrast, DPP did not bind significant amounts of $\mathrm{Ca}^{2+}$.

CPP effectively inhibited the formation of insoluble calcium phosphates at different $\mathrm{Ca} / \mathrm{P}$ ratios. The effective $\mathrm{CPP}$ concentration was $10 \mathrm{mg} / \mathrm{l}$ and complete stability of calcium phosphate solutions was obtained at about $100 \mathrm{mg} / \mathrm{l}$. This stabilizing effect was dependent on the presence of organic $\mathbf{P}$.
\end{abstract}

Casein phosphopeptides are formed during in vivo digestion of casein and their role in controlling luminal concentrations of soluble Ca was emphasized by Lee et al. (1980). They can stabilize calcium phosphate solutions in vitro (Reeves \& I atour, 1957), and interfere with the formation of amorphous or crystalline calcium phosphate. This allows high concentrations of $\mathrm{Ca}^{2+}$ to exist in the presence of inorganic phosphate (Gerber \& Jost, 1986).

We have produced tryptic phosphopeptides from whole casein (Juillerat et al. 1989 ) and studied their Ca binding properties as well as their power of inhibiting the formation of insoluble calcium phosphates, the specific role of peptide-linked phosphoester groups being examined by comparison with an enzymically dephosphorylated peptide preparation.

\section{MATERIAL AND METHODS}

A pool of casein phosphopeptides (CPP) and a phosphopeptide fraction (PPF) mainly composed of fragments $\beta-\mathrm{CN}(1-28): 4 \mathrm{P}, \quad \beta-\mathrm{CN}(2-28): 4 \mathrm{P}$ and $\alpha_{\mathrm{si}^{-}}$ $\mathrm{CN}(59-79): 5 \mathrm{P}$, were prepared as described by Juillerat et al. (1989). Dephosphorylated peptides (DPP) were obtained by enzymic hydrolysis of CPP with potato acid phosphatase EC 3.1.3.2, grade II from Boehringer Mannheim GmbH, West Germany, according to Gerber \& Jost (1986).

${ }^{45} \mathrm{CaCl}_{2}$ was a product from Amersham Chemicals, U.K. 


\section{Calcium binding experiments}

The $\mathrm{Ca}^{2+}$-binding isotherms for each fraction CPP, PPF and DPP were obtained from measurements of free $\mathrm{Ca}^{2+}$ with a $\mathrm{Ca}$ selective electrode, Phillips IS 561, connected to an Orion EA940 IonAnalyzer. Solutions $(50 \mathrm{ml})$ containing $100 \mathrm{mg}$ of peptide, as the $\mathrm{Na}$ salt, and $186.4 \mathrm{mg}$ of $\mathrm{KCl}$ to adjust the ionic strength were titrated with $0 \cdot 1 \mathrm{M}-\mathrm{CaCl}_{2}$. The $\mathrm{pH}$ was kept constant at the desired value by addition of $0 \cdot 25$ $\mathrm{M}-\mathrm{NaOH}$ or $0.25 \mathrm{M}-\mathrm{HCl}$, and the temperature was maintained at $25^{\circ} \mathrm{C}$. Free $\mathrm{Ca}^{2+}$ was measured after each $50 \mu \mathrm{l}$ addition of $\mathrm{CaCl}_{2}$ solution, and the concentrations of total $\mathrm{Ca}^{2+}$ and peptide were corrected for dilution. The bound $\mathrm{Ca}^{2+}$ per mole of ligand was calculated by subtracting the free $\mathrm{Ca}^{2+}$ from the total $\mathrm{Ca}^{2+}$, and dividing by the ligand concentration, using an average molecular weight of 2000 Daltons. The peptides were named respectively CPP2000 or DPP2000, for intact and dephosphorylated phosphopeptides. Alternatively, the bound $\mathrm{Ca}^{2+}$ was calculated on the basis of the organic phosphorus content of CPP and PPF.

The apparent association constants $\left(K_{\mathrm{app}}\right)$ and the maximum Ca bound per mole of ligand were calculated using a standard Klotz plot analysis (Regenstein \& Regenstein, 1984).

\section{Potentiometric titration during apatite precipitation}

Solutions containing $0.008 \mathrm{M}-\mathrm{NaH}_{2} \mathrm{PO}_{4}$ and $0.008 \mathrm{M}-\mathrm{CaCl}_{2}$ and either $0,0 \cdot 1$ or 0.2 $\mathrm{g} / \mathrm{l} \mathrm{CPP}$ or $0.53 \mathrm{~g} / \mathrm{l}$ of DPP were titrated in a thermostatted reactor with $0.1 \mathrm{~m}$ $\mathrm{NaOH}$, at $25^{\circ} \mathrm{C}$. The $\mathrm{pH}$ was maintained at 7.4 using a $\mathrm{pH}$-stat unit Radiometer RTS 822 equipped with an autoburette Radiometer ABU 80, and a Radiometer REA160 recorder.

\section{Calcium phosphate precipitation at variable $\mathrm{Ca} / \mathrm{P}$ molar ratio}

Formation and precipitation of insoluble calcium phosphate, and its inhibition by phosphopeptides was also measured with a ${ }^{45} \mathrm{Ca}$ isotope technique. $\mathrm{CaCl}_{2}$ solutions and $\mathrm{NaH}_{2} \mathrm{PO}_{4}$ solutions in Tris- $\mathrm{HCl}$ buffer $0.05 \mathrm{M}, \mathrm{pH} 7.5$ and $0.1 \mathrm{M}$ in $\mathrm{KCl}$ were mixed to give different $\mathrm{Ca} / \mathrm{P}$ molar ratios in the range $0 \cdot 8-2 \cdot 0$, at a constant molar product $\mathrm{Ca} \times \mathrm{P}$ of $20 \mathrm{~mm}^{2}$. Phosphopeptides were added at concentrations ranging from 0 to $500 \mathrm{mg} / \mathrm{l}$. The solutions were traced with ${ }^{45} \mathrm{Ca}, 30000 \mathrm{dpm} / \mathrm{ml}$.

Portions $(2 \mathrm{ml})$ of each solution were incubated in presence or absence of CPP at $40^{\circ} \mathrm{C}$ for $30 \mathrm{~min}$ in a water bath. After rapid cooling of the tubes in an ice bath, precipitated calcium phosphate was removed by filtration through disposable ACRO LC 13 filters of 0.45 micron pore size (Gelman Sciences Inc. Ann Arbor, USA). Each filtrate $(1 \mathrm{ml})$ was mixed in a scintillation vial with $1 \mathrm{ml}$ of EDTA solution $(0.01 \mathrm{M}$ in Tris buffer) and $15 \mathrm{ml}$ of scintillator (Optifluor, United Technology Packard, Packard Instruments International, Zürich), and was counted using a Searle Mark IV instrument.

Total, inorganic and derived organic phosphorus content of peptides was determined (Juillerat et al. to be published).

\section{RESULTS}

\section{Calcium binding}

The binding isotherms obtained for the system Ca-CPP2000 showed that bound $\mathrm{Ca}^{2+}$ increased towards a plateau as the free $\mathrm{Ca}^{2+}$ concentration was increased. DPP2000 did not bind $\mathrm{Ca}^{2+}$ to any significant extent (Fig. 1). The Klotz plots 


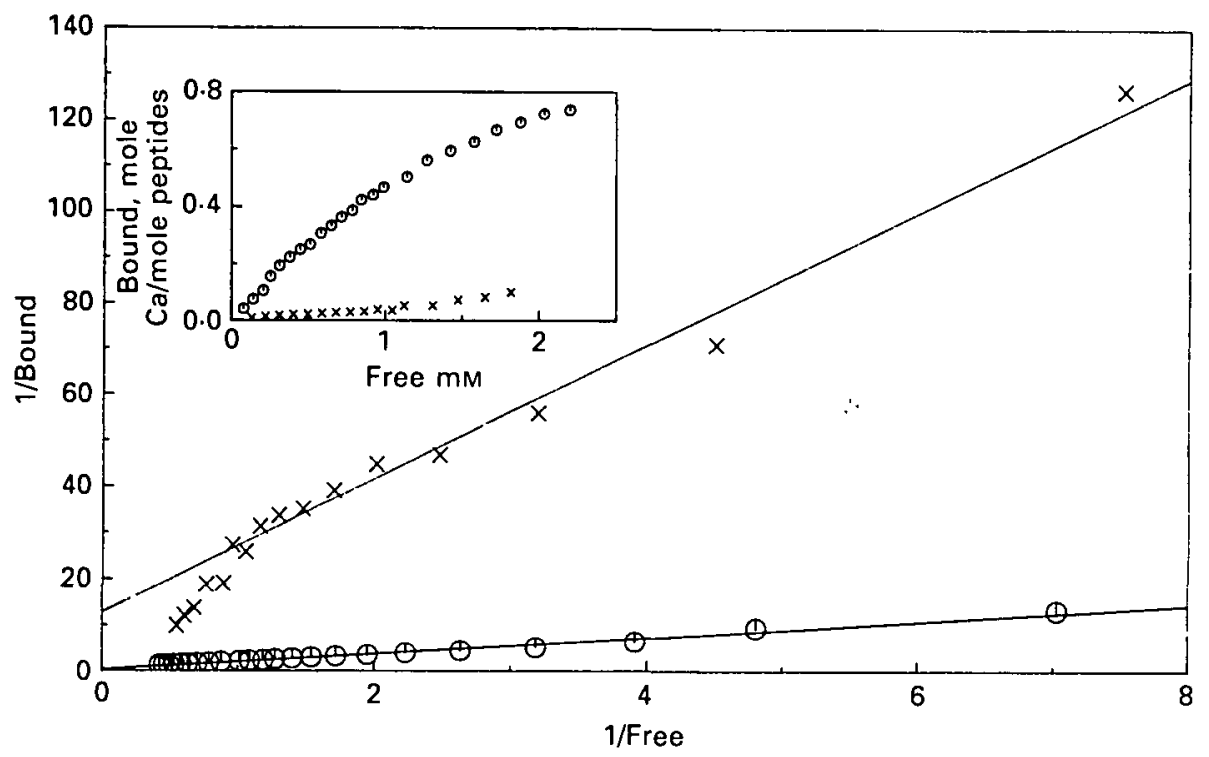

Fig. 1. Klotz plots and binding isotherms of $\mathrm{Ca}^{2+}$ to $\mathrm{CPP}(\mathrm{O})$ and $\mathrm{DPP}(X)$ at $\mathrm{pH} 6.5,25{ }^{\circ} \mathrm{C}$ and an ionic strength of $0.1 \mathrm{M}(\mathrm{KCl})$, using an assumed molecular weight of 2000 Daltons for the peptides.

Table 1. Apparent binding constants $\left(K_{\text {app }}\right)$ and maximum bound Ca obtained for $C P P, D P P$ and PPF from Klotz plot analysis

\begin{tabular}{|c|c|c|c|}
\hline & $\mathrm{pH}$ & $\begin{array}{l}\text { Bound Ca } \\
\text { mole/mole }\end{array}$ & $\begin{array}{c}K_{\text {app }} \\
1 / \text { mole }\end{array}$ \\
\hline ('Pl:2000* & 6.5 & 30 & 189 \\
\hline DPP2000* & 65 & 0.08 & 871 \\
\hline ('PP† & $6 \% 5$ & 0.81 & $4(i \pi)$ \\
\hline PPF† & $3 \cdot 5$ & 0.11 & 662 \\
\hline PPF+ & 65 & 0.91 & 640 \\
\hline $\mathrm{PPF}^{\dagger}$ & $7 \cdot 6$ & $0 \cdot 96$ & 2060 \\
\hline
\end{tabular}

* Per mole of peptide, molecular weight 2000 .

+ Per mole of organic phosphate.

calculated from these two isotherms are shown in Fig. 1. The system Ca-CPP2000 gave a straight line indicating a defined number of equivalent binding sites showing a low affinity for $\mathrm{Ca}^{2+}$, and a maximum bound $\mathrm{Ca}^{2+}$ of 3 mole/mole of CPP2000. The result was different for the pair Ca-DPP2000, where the Klotz plot was not linear suggesting heterogeneous binding sites. The maximum bound $\mathrm{Ca}^{2+}$ and the apparent association constant $\left(K_{\text {app }}\right)$, calculated from the first part of the binding isotherm, up to a $50 \%$ saturation are shown in Table 1 . The data for $\mathrm{Ca}^{2+}$ binding to CPP were also analysed according to Klotz on the basis of their organic phosphorus content $\left(\mathrm{P}_{\text {org }}\right)$. Again, a straight line was found indicating the equivalence of all the phosphate groups present in CPP (data not shown). The maximum amounts of bound $\mathrm{Ca}^{2+}$ and the corresponding $K_{\text {app }}$ are shown in Table 1.

The same determination was undertaken with the more homogeneous phosphopeptide fraction PPF. All three phosphopeptides contained in this fraction share the same highly negative charged subsequence: Glu-SerP-Leu-SerP-SerP-SerP-GluGilu. Binding isotherms expressed on the basis of the $P_{\text {org }}$ of PPF and determined at 


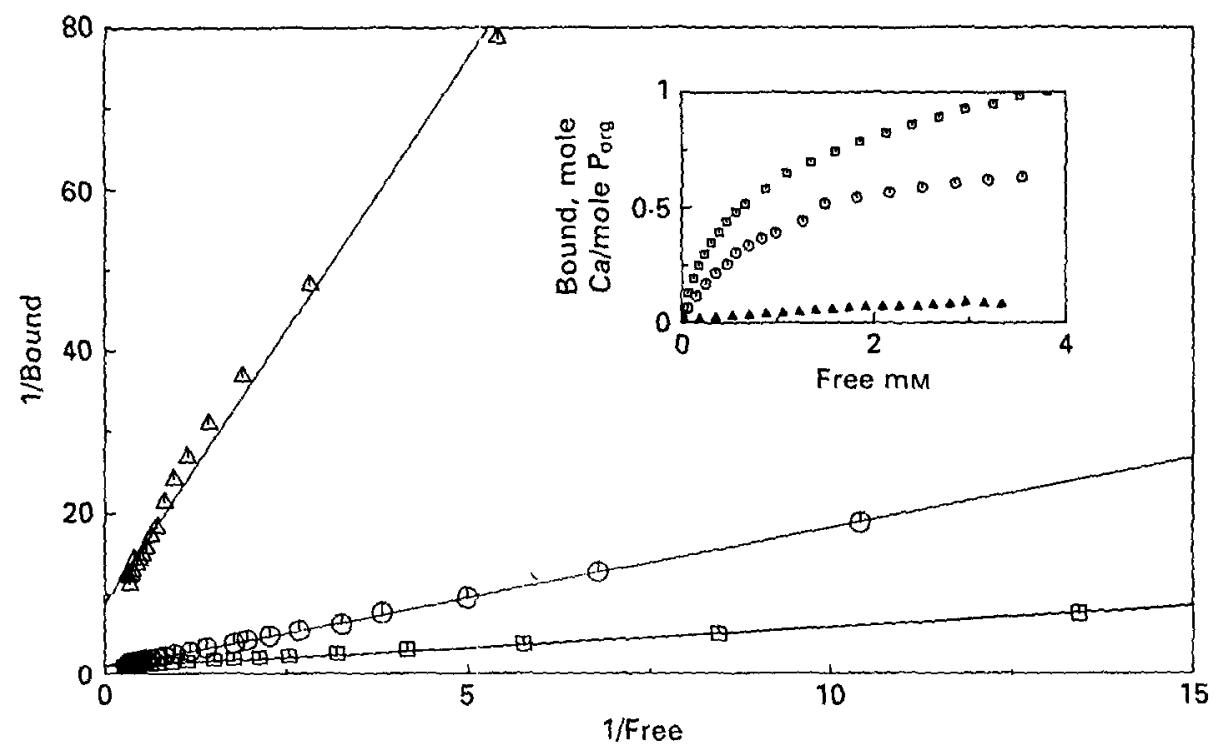

Fig. 2. Klotz plots and binding isotherms of Ca to PPF, expressed on the basis of their $P_{\text {org }}$ at the $p H$ values $3.5(\Delta), 6.5(\mathrm{O})$ and $7.6(\mathrm{D})$. Ionic strength set at $0.1 \mathrm{M}$ with $\mathrm{KCl}$ and temperature at $25^{\circ} \mathrm{C}$.

three different $\mathrm{pH}$ values 35,65 and 76 , are shown in Fig. 2 . As expected, the bound $\mathrm{Ca}^{2+}$ increased when the $\mathrm{pH}$ was raised.

The Klotz plots derived from the isotherms again gave straight lines at the $\mathrm{pH}$ values of 6.5 and $7 \cdot 6$, indicating the equivalence of all phosphate groups at these two $\mathrm{pH}$ values (Fig. 2) and with a stoicheiometry $\mathrm{Ca} / \mathrm{P}_{\text {org }}$ of practically $1 / 1$. A slight deviation from the straight line was obtained at $\mathrm{pH} 3 \cdot 5$, possibly due to the low degree of dissociation of phosphate groups compared with that of carboxyl groups. Nevertheless, the linear regression coefficient obtained for the Klotz plot was still 0.989 and therefore all the data points were used for the calculations of the maximum bound Ca and the $K_{\text {app }}$ (Table 1). The $K_{\text {app }}$ obtained at $\mathrm{pH}$ values 3.5 and 6.5 were practically identical, whereas at $\mathrm{pH} 7.6$ an unexplained three-fold increase of $K_{\text {app }}$ was measured (Table 1).

\section{Inhibition of apatite precipitation}

The spontaneous transformations of calcium phosphate solutions according to the two following reactions,

$$
\begin{aligned}
& \text { (1) } \mathrm{Ca}\left(\mathrm{H}_{2} \mathrm{PO}_{4}\right)_{2} \longrightarrow \mathrm{CaHPO}_{4}+\mathrm{H}_{2} \mathrm{PO}_{4}^{-}+\mathrm{H}^{+} \\
& \text {(2) } 3 \mathrm{CaHPO}_{4} \longrightarrow \mathrm{Ca}_{3}\left(\mathrm{PO}_{4}\right)_{2}+\mathrm{HPO}_{4}^{2-}+2 \mathrm{H}^{+}
\end{aligned}
$$

both liberate $\mathrm{H}^{+}$ions. It is therefore possible to monitor indirectly the effect of CPP on these reactions using a pH-stat. Fig. 3 shows the inhibition of these transformations by CPP. At a molar product $\mathrm{Ca} \times \mathrm{P}$ of $64 \mathrm{~mm}^{2}$ and at a molar ratio $\mathrm{Ca} / \mathrm{P}$ of 1 , the inhibition depends on the concentration of CPP present in solution. $0.1 \mathrm{~g} \mathrm{CPP} / \mathrm{l}$ (corresponding to $3 \mathrm{mg} P_{\text {org }}$ ) just delays the precipitation, while a CPP concentration of $0.2 \mathrm{~g} / 1$ completely prevents the precipitation of calcium phosphate salts. For comparison, the same measurement was made with $0.53 \mathrm{~g} / \mathrm{l}$ of $\mathrm{DPP}$, which 


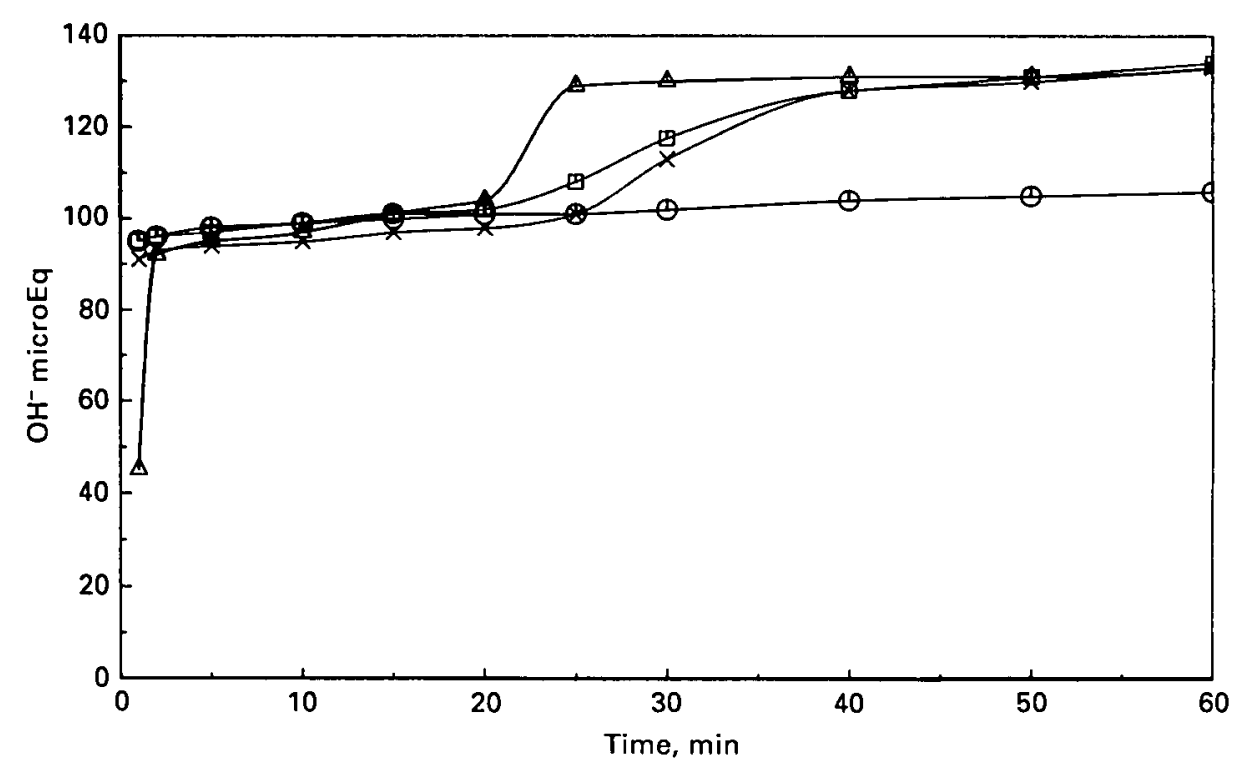

Fig. 3. Inhibition of calcium phosphate precipitation from a solution of $0.008 \mathrm{M}-\mathrm{CaCl}_{2}$ and $\mathrm{NaH}_{2} \mathrm{PO}_{4}$ as measured by titration with $0 \cdot 1 \mathrm{M}-\mathrm{NaOH}$ to $\mathrm{pH}$ at $7 \cdot 4$, at a temperature of $25{ }^{\circ} \mathrm{C}$. Control (no peptides) $(\triangle)$; CPP 0.1 g/l ( $\square$ ); CPP $0.2 \mathrm{~g} / \mathrm{l}(\mathrm{O})$; DPP $0.53 \mathrm{~g} / \mathrm{l}(\times)$.

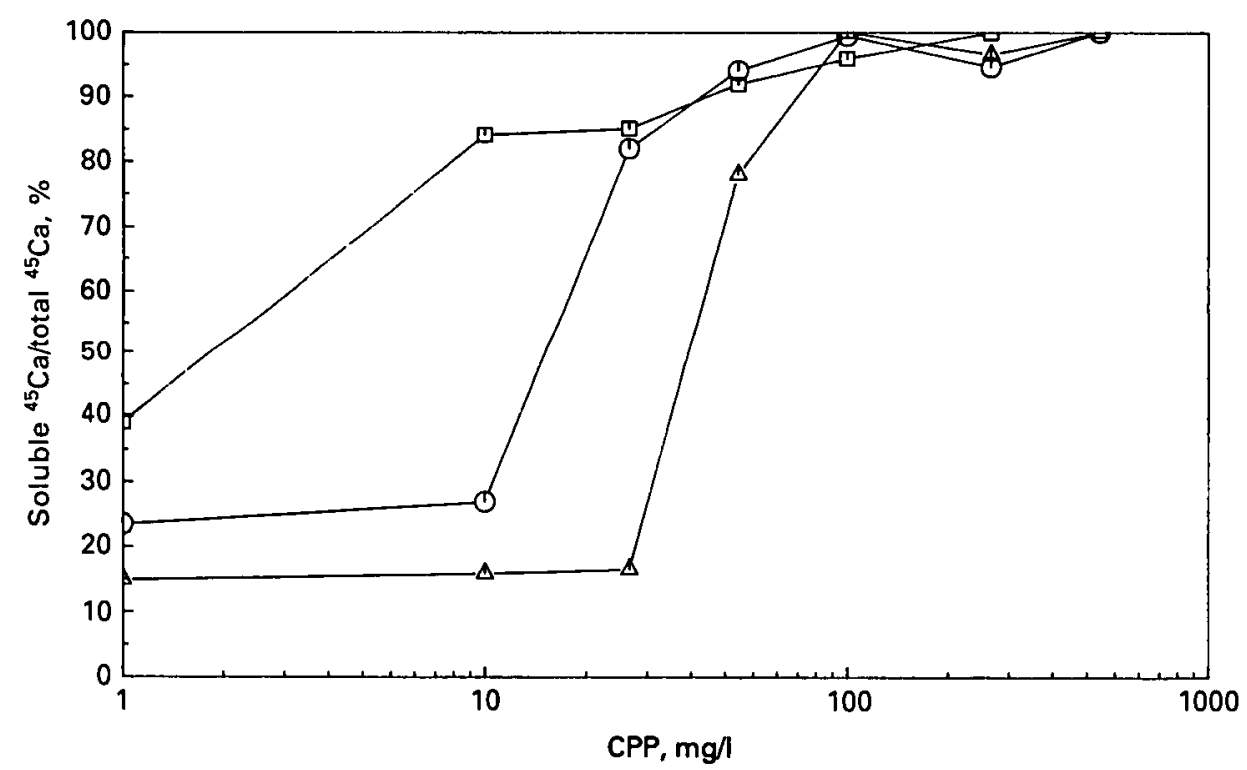

Fig. 4. Effect of CPP concentration on calcium phosphate solubility $\left(\mathrm{Ca} \times \mathrm{P}=20 \mathrm{~mm}^{2}\right)$ at molar $\mathrm{Ca} / \mathrm{P}$ ratios of $0.8(\triangle) ; 1.25(O)$ and $1.95(\square)$. Further conditions were: $40^{\circ} \mathrm{C}$ for $30 \mathrm{~min}$, at $\mathrm{pH} 7.4$ and an ionic strength of $0.1 \mathrm{M}$; tracing with $30000 \mathrm{dpm} / \mathrm{ml}$ of ${ }^{45} \mathrm{CaCl}_{2}$.

even at the higher concentration, was unable to prevent the precipitation of calcium phosphates (Fig. 3).

CPP were shown to inhibit formation of insoluble calcium phosphate, as measured by the loss of soluble ${ }^{45} \mathrm{Ca}$ during incubation of calcium phosphate solutions at $40^{\circ} \mathrm{C}$. All solutions with molar products $\mathrm{Ca} \times \mathrm{P}$ higher or equal to $16 \mathrm{~mm}^{2}$ 
lost up to $80 \%$ of their $\mathrm{Ca}^{2+}$ by precipitation within 20 min of incubation. CPP at concentrations of $10 \mathrm{mg} / \mathrm{l}$ or higher inhibited this precipitation reaction effectively. Depending on the $\mathrm{Ca} / \mathrm{P}$ molar ratio, different dose-response curves were obtained (Fig. 4). In our experimental conditions, complete stability was achieved with 100 $\mathrm{mg} / \mathrm{l}$ of CPP. DPP were ineffective, even at concentrations higher than $100 \mathrm{mg} / \mathrm{l}$.

\section{DISCUSSION AND CONCLUSIONS}

The results on $\mathrm{Ca}^{2+}$-binding ('Table 1), show that CPP2000 binds Ca weakly, with a $K_{\text {app }}$ equal to $185 \mathrm{l} /$ mole, lower than the first binding constant of $398 \mathrm{l} / \mathrm{mole}$ for $\alpha_{\mathrm{s} 1}$-casein (Sillen \& Martel, 1964) but very close to the $200 \mathrm{l} / \mathrm{mole}$ reported by the same authors for the system Ca-phosphoserine. Also, the binding constants of 640 $1 /$ mole and $465 \mathrm{l} /$ mole determined at $\mathrm{pH} 6.5$ for Ca-PPF and Ca-CPP respectively, on the basis of their $\mathrm{P}_{\text {org }}$, can also be compared to the average binding constant of 574 and $519 \mathrm{l} /$ mole reported by Parker \& Dalgleish (1980) for $\mathrm{Ca}^{2+}$ binding to phosphoseryl residues of $\alpha_{\mathrm{s} 1^{-}}$and $\beta$-casein at $\mathrm{pH} 7$ and $20^{\circ} \mathrm{C}$. This observation suggests that the phosphoseryl residues in caseins and the derived CPP and PPF are similarly accessible. Our results show clearly that the binding sites for $\mathrm{Ca}^{2+}$ are essentially the phosphoserine residues. They all appear equivalent and the stoicheiometry $\mathrm{Ca} / \mathrm{P}_{\text {org }}$ is approximately $1 / 1$ at $\mathrm{pH} 6.5$ and 7.6. The Klotz plot obtained at $\mathrm{pH} 3.5$ may suggest more than one class of binding sites, but the phosphoserine residues are preferentially filled. $\mathrm{pH}$ affects $\mathrm{Ca}^{2+}$ binding to phosphopeptides similarly to its effect on caseins (Dickson \& Perkins, 1971), the lower stoicheiometry found at $\mathrm{pH} 3.5$ being related to the low extent of dissociation of phosphoseryl residues at this $\mathrm{pH}$. On the other hand, the carboxyl groups seem unable to bind a significant amount of Ca, since the Ca bound by DPP2000 is very low, and the calculated $K_{\mathrm{app}}$ has not perhaps any real physical significance.

The ability of $0.2 \mathrm{~g} / \mathrm{l}$ of CPP to prevent the precipitation of $0.008 \mathrm{M}$ of calcium phosphate salts, and the ineffectiveness of $0.53 \mathrm{~g} / \mathrm{l}$ of DPP, confirm the essential role played by the phosphoseryl groups in $\mathrm{Ca}^{2+}$-phosphopeptide interactions. The mechanism by which CPP can maintain high concentrations of soluble calcium in solution, even in presence of high concentrations of inorganic phosphate is not yet fully understood. Nevertheless, the stabilizing effect depends on both the molar ratio $\mathrm{Ca} / \mathrm{P}$ and the CPP concentration present in solution (Fig. 4). Our results support the work previously reported by Reeves \& Latour (1958) and confirm those reported by Gerber and Jost (1986), showing the same phenomenon in an in vitro model. Furthermore, it may explain the observations of Naito et al. (1972) and Lee et al. (1980) who noted the ability of phosphopeptides detected in vivo, in rats on a casein diet, to increase luminal Ca concentration.

\section{REFERENCES}

Dickson, I. R. \& Perkins, D. J. 1971 Studies on the interactions between purified bovine caseins and alkaline-earth metal ions. Biochemical Journal $124235-240$

Gerber, H. W. \& Jost, R. 1986 Casein phosphopeptides: their effect on calcification of in vitro cultured embryonic rat bone, Calcified Tissue International 38 350-357

Julllerat, M. A., Bafchler, R., Berrocal, R., Chanton, S., Scherz, J.-C. \& Jost, R. 1989 Tryptic phosphopeptides from whole casein. I. Preparation and analysis by fast protein liquid chromatography. Journal of Dairy Research 56 in press.

Lee, Y. S., Noguchi, T. \& Naito, H. 1980 Phosphopeptides and soluble calcium in the small intestine of rats given a casein diet. British Journal of Nutrition $43457-467$ 
Natro, H., Kawakami, A. \& Imamura, T. 1972 In vivo formation of phosphopeptide with Ca-binding property in the small intestimal tract of the rat fed on casein. Agriculural and Biological Chemistry $36409-415$

Pakkek, T. G. \& Dalcileish, D. G. 1981 Binding of calcium ions to bovine $\beta$-casein. Journal of Dairy Research $4871-76$

Rezves, R. E. \& Latrouk, N. G. 1958 Calcium phosphate sequestering phosphopeptide from casein. Science $128+72$

Regenstein, J. M. \& Regenstein, C. E. 1984 In Food Protein Chemistry pp. 180-191. Orlando: Academic Press

Silles, L. G. \& Martel, A. E. 1964 Stability constants of metal ion complexes (Special Publications of ('hemical Society no. 17) London: Chemical Society 